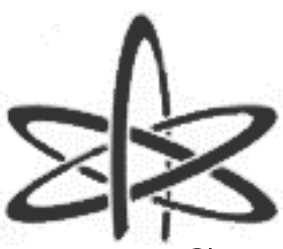

BJRS

\author{
BRAZILIAN JOURNAL \\ $\mathrm{OF}$ \\ RADIATION SCIENCES \\ 05-03-A (2017) 01-07
}

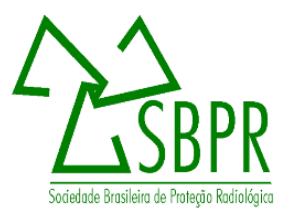

\title{
Study of a new glass matrix by thermoluminescent technique for high-dose dosimetry
}

\author{
P.Z. Ferreira ${ }^{\text {a }}$ G. S. M. Carvalho ${ }^{\text {a }}$ N. O. Dantas ${ }^{a}$, A. C. A. Silva ${ }^{a}$, L. P. Neves ${ }^{a, b}$, \\ L. V. E. Caldas ${ }^{b}$, B. N. S. Carrera ${ }^{c}$, S. Watanabe ${ }^{c}$, A. P. Perini ${ }^{a}$
}

anstituto de Física, Universidade Federal de Uberlândia (INFIS/UFU), Caixa Postal 593, 38400-902, Uberlândia,

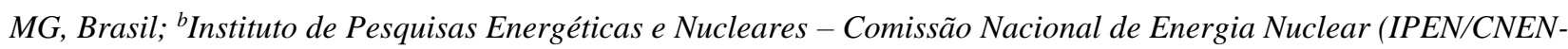
SP), 05508-000, São Paulo, SP, Brasil; 'Instituto de Física da Universidade de São Paulo (IFUSP), 05508-090, São Paulo, SP, Brasil anapaula.perini@ufu.br

\begin{abstract}
The thermoluminescence technique is widely used for both personal and high-dose dosimetry. In this work, the thermoluminescence technique was employed to study a new glass matrix, with nominal composition of $20 \mathrm{Li}_{2} \mathrm{CO}_{3} .10 \mathrm{Al}_{2} \mathrm{O}_{3} .30 \mathrm{BaO} .40 \mathrm{~B}_{2} \mathrm{O}_{3}(\mathrm{~mol} \%)$, irradiated with different doses in a ${ }^{60} \mathrm{Co}$ radioactive source. The glow curves and the dose-response curve were obtained for radiation doses of 10, 50, 100, 200 and $700 \mathrm{~Gy}$. The results showed that this new glass matrix has potential use in high-dose dosimetry.

Keywords: dosimetry, thermoluminescence, new glass matrix.
\end{abstract}




\section{INTRODUCTION}

Thermoluminescence is the phenomenon characterized by the emission of light from a heated material, which was previously irradiated. The quantity of light emitted is proportional to the dose absorbed by the material. Thermoluminescent (TL) materials are generally ionic crystals. The energy band model is employed to describe the phenomenon of operation of these materials. When an impurity is inserted into the crystal structure, capture centers (traps) may be created in the forbidden band. The TL signal shows peaks at certain temperatures associated with a trap $[1,2]$.

Some important features are important for a TL dosimeter, such as high sensitivity, linear response for a wide dose range, stability and a glow curve with a single thermoluminescent peak [1]. There are several materials that can be applied in thermoluminescence, both natural and artificial. Among the natural materials we can mention the $\mathrm{BeO}, \mathrm{Al}_{2} \mathrm{O}_{3}$ and $\mathrm{CaF}_{2}$ (fluorite), while among the artificial materials the most used are: LiF:Mg,Ti; LiF:Mg,P,Cu; LiF:Dy; $\mathrm{CaSO}_{4}: \mathrm{Dy} ; \mathrm{Li}_{2} \mathrm{~B}_{4} \mathrm{O}_{7}: \mathrm{Mn}$; $\mathrm{Li}_{2} \mathrm{~B}_{4} \mathrm{O}_{7}: \mathrm{Cu}$ [1]. Between these materials, the most popular in dosimetry is the $\mathrm{LiF}: \mathrm{Mg}, \mathrm{Ti}$ [1].

Currently, researches are being done to improve the characteristics of TL materials through their preparation, using different methods of synthesis or by doping with different impurities $[3,4]$. Some glasses also have the potential to be applied as dosimeters. One of the advantages of using glass as a radiation detector is that it has small size, making it easy to handle, and a low production costs $[5]$.

The thermoluminescent technique can be applied to environmental, personnel and high-doses dosimetry. The high-dose dosimetry, which involves doses between $10 \mathrm{~Gy}$ to $100 \mathrm{kGy}$, is becoming more and more common, being applied in activities such as: gammagraphy, sterilization of surgical materials, food irradiation, curing inks and varnishes, irradiation of semiprecious stones, polymerization cables and activities with nuclear reactors, among other activities [6]. 
In order to control the radiation doses involved in such practices, in this study a new glass matrix, with nominal composition $20 \mathrm{Li}_{2} \mathrm{CO}_{3} \cdot 10 \mathrm{Al}_{2} \mathrm{O}_{3} \cdot 30 \mathrm{BaO} \cdot 40 \mathrm{~B}_{2} \mathrm{O}_{3}(\mathrm{~mol} \%)$, was characterized using thermoluminescence technique for high-dose dosimetry. This glass matrix was analyzed for different doses.

\section{MATERIALS AND METHODS}

\section{1 The vitreous system synthesis}

The sample was synthesized by traditional fusion method in silicon carbide furnace at $1350^{\circ} \mathrm{C}$ for 15 minutes under an atmosphere of carbon. The melt was rapidly cooled by pressing it between two brass plates at approximately $0^{\circ} \mathrm{C}$ which yielded glass sheets. The samples were pulverized and selected by granulometric analysis with grains of $0.180 \mathrm{~mm}$ in diameter.

\section{2 Irradiation}

The irradiations were performed at room temperature on a Gamma-cell system $220\left({ }^{60} \mathrm{Co}\right)$, manufactured by the Atomic Energy of Canada, model 220, with a dose rate of $1.38 \mathrm{kGy} / \mathrm{h}$. This system is located at the Radiation Technology Center (Centro de Tecnologia das Radiações - CTR) of Instituto de Pesquisas Energéticas e Nucleares (IPEN/CNEN-SP), a Research Institution located in São Paulo, Brazil. In order to keep the electronic equilibrium conditions of the samples during irradiation, lucite plates with $4 \mathrm{~mm}$ of thickness were used. The irradiation doses utilized were: 10, 50, 100, 200, and 700 Gy. 


\section{3 Thermoluminescence measurements}

The thermally stimulated measurements were performed in a Harshaw TLD reader system, model 4500 , with a personal computer for data acquisition (Figure 1). The measurements were taken from room temperature to $400^{\circ} \mathrm{C}$ using a constant flow of $2.5 \mathrm{~L} / \mathrm{min}$ of $\mathrm{N}_{2}$ and a heating rate of $10^{\circ} \mathrm{C} / \mathrm{min}$.

Figure 1: Thermoluminescence system used to obtain the thermoluminescence measurements

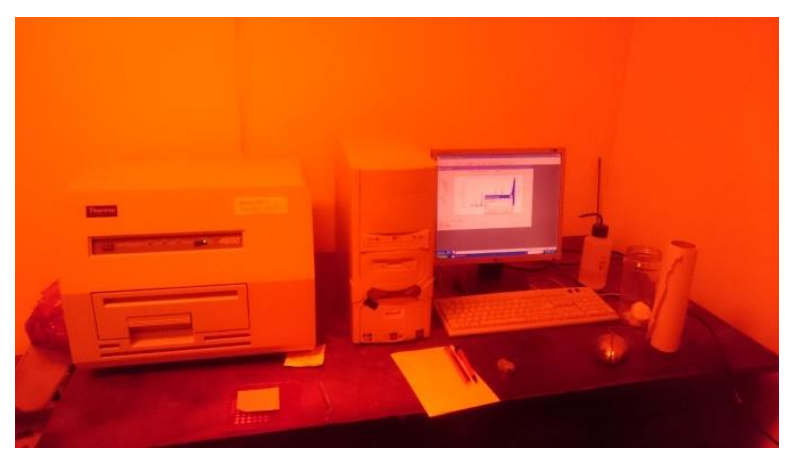

The dose-response curve is represented by the thermoluminescence response of the material as a function of the absorbed dose. To obtain the dose-response curve, the glass matrix was irradiated with doses between $10 \mathrm{~Gy}$ and $700 \mathrm{~Gy}$. For each dose, five measurements were made in order to determine the standard deviation of each dose.

\section{RESULTS AND DISCUSSION}

In order to characterize the new glass matrix, the thermoluminescence glow curves and the doseresponse curve were obtained. The following sections present the results. 


\subsection{The thermoluminescence glow curves}

The glow curves of the new glass matrix, showed in Figure 2, were obtained for different doses: 10, $50,100,200$, and $700 \mathrm{~Gy}$. It is possible to observe that the thermoluminescence intensity increases with the absorbed dose. When comparing the intensity of the thermoluminescence signal for the analyzed doses, it can be seen that the doses of 10, 50, 100 and 200 Gy does not present a welldefined peak as the dose of $700 \mathrm{~Gy}$, which has a clear peak at $180^{\circ} \mathrm{C}$. For dosimetry purposes, the detector, characterized by the TL emission curve, must have a peak preferably between $200^{\circ} \mathrm{C}$ and $250{ }^{\circ} \mathrm{C}$ [1]. The temperature may be high enough to ensure room temperature stability, but not so high as to present instrumental problems [1].

Figure 2: Thermoluminescence glow curves of the glass matrix with nominal composition $20 \mathrm{Li}_{2} \mathrm{CO}_{3} .10 \mathrm{Al}_{2} \mathrm{O}_{3} .30 \mathrm{BaO} .40 \mathrm{~B}_{2} \mathrm{O}_{3}$ (mol\%) for high doses

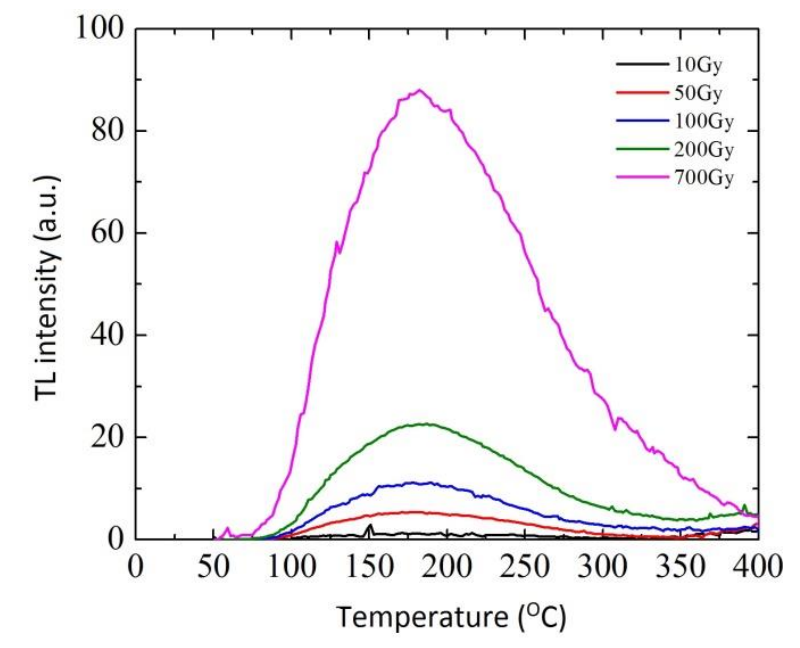

\subsection{Dose-response curve}

A sublinear behavior of the dose-response curve, shown in Figure 3, is observed for the measured doses. Therefore, the glass matrix analyzed in this work can be applied for high-dose dosimetry, with the dose range used in this work. 
Figure 3: Dose-response curve of the glass matrix with nominal composition $20 \mathrm{Li}_{2} \mathrm{CO}_{3} .10 \mathrm{Al}_{2} \mathrm{O}_{3} .30 \mathrm{BaO} .40 \mathrm{~B}_{2} \mathrm{O}_{3}$ (mol\%), with their respective uncertainties

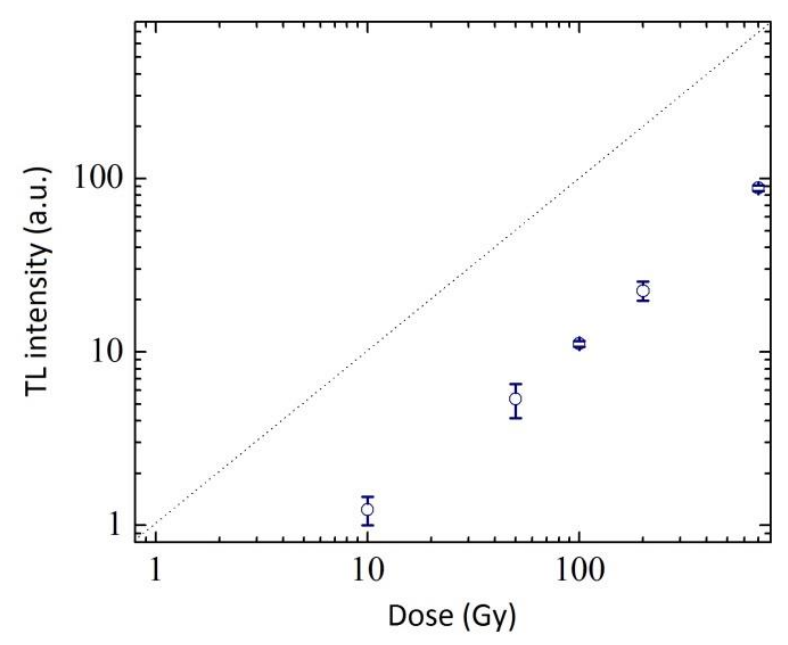

\section{CONCLUSION}

In this work a new glass matrix was studied and analyzed for use in high-dose dosimetry. This new glass matrix was irradiated with different doses: 10, 50, 100, 200 and 700 Gy. From the results obtained, it can be observed that this glass matrix has potential use as a detector for high dose, which is related to activities such as gammagraphy, sterilization of surgical materials, food irradiation, curing inks and varnishes, irradiation of semiprecious stones, polymerization cables, among other activities.

\section{ACKNOWLEDGMENT}

This work was supported in part by the Brazilian agencies: Fundação de Amparo à Pesquisa do Estado de Minas Gerais (FAPEMIG, Grant no. APQ-02934-15), CAPES (Grant Pro-Estratégia no. 1999/2012), CNPq (Grants no. 304789/2011-9, 157593/2015-0, 421603/2016-0 and 420699/20163) and INCT for Radiation Metrology in Medicine. 


\section{REFERENCES}

1. McKEEVER, S., MOSCOVITCH, M., TOWNSEND, P. Thermoluminescence Dosimetry Materials: Properties and Uses. Ramtrans Publishing, 1995.

2. CAMPOS, L. L. Termoluminescência de materiais e sua aplicação em dosimetria da radiação. Cerâmica, São Paulo, v. 44, p. 244-251, 1998.

3. HOROWITZ, Y., OLKO, P. The effects of ionization density on the thermoluminescence response (efficiency) of LiF:Mg,Ti and LiF:Mg,Cu,P. Radiat Prot Dosim, v. 109, p. 331-348, 2004.

4. ZAHEDIFAR, M., SADEGHI, E. Thermoluminescence dosimetry properties of new Cu doped CaF2 nanoparticles. Radiat Prot Dosim, v. 157, p. 303-309, 2013.

5. TEIXEIRA, M. I. Propriedades dosimétricas de vidros comerciais e de areia para doses altas. 2004. Tese de Doutorado. Universidade de São Paulo, São Paulo. 2004.

6. McLAughlin, W.L., BOYD, A.W., CHADWICK, K.H., MCDONALD, J.C., MiLlER, A. Dosimetry for radiation processing. CRC press, 1 edition, 1989. 